AGRITECH, Vol. 37, No. 1, Februari 2017, Hal. 88-94 DOI: http://dx.doi.org/10.22146/agritech.10454

ISSN 0216-0455 (Print), ISSN 2527-3825 (Online)

Tersedia online di https://jurnal.ugm.ac.id/agritech/

\title{
Aktivitas Antioksidan Kulit Biji Kakao dari Hasil Penyangraian Biji Kakao Kering pada Derajat Ringan, Sedang dan Berat
}

\author{
Antioxidant Activity from Shell of Roasted Cocoa Bean with Low, Medium and High Roasting Degree \\ Ratri Retno Utami', S. Supriyanto², Sri Rahardjo ${ }^{2}$, Ria Armunanto ${ }^{3}$ \\ ${ }^{1}$ Balai Besar Industri Hasil Perkebunan, Kementerian Perindustrian, Jl. Prof. Dr. Abdurrahman Basalamah No. 28, \\ Makassar, Sulawesi Selatan 90231, Indonesia \\ ${ }^{2}$ Departemen Teknologi Pangan dan Hasil Pertanian, Fakultas Teknologi Pertanian, Universitas Gadjah Mada, \\ Jl. Flora No. 1, Bulaksumur, Yogyakarta 55281, Indonesia \\ ${ }^{3}$ Departemen Kimia, Fakultas Matematika dan Ilmu Pengetahuan Alam, Universitas Gadjah Mada, \\ Sekip Utara, Bulaksumur, Yogyakarta 55281, Indonesia \\ Email: ratri.retno.u@gmail.com
}

Submisi: 19 Januari 2016; Penerimaan: 12 April 2016

\begin{abstract}
ABSTRAK
Kulit biji kakao merupakan limbah dari industri pengolahan cokelat yang mengandung polifenol sebesar 5,78\%, sehingga berpotensi untuk dimanfaatkan sebagai sumber senyawa antioksidan alami. Tahapan penting dalam pengolahan biji kakao kering adalah penyangraian yang berguna untuk pengembangan citarasa khas cokelat. Industri pengolahan cokelat melakukan penyangraian dengan derajat ringan, sedang dan berat, berdasarkan produk yang dikehendaki. Penelitian ini bertujuan untuk mengetahui pengaruh derajat penyangraian terhadap aktivitas antioksidan kulit biji kakao. Biji kakao kering disangrai pada derajat ringan $\left(110^{\circ} \mathrm{C}\right.$ selama 60 menit), sedang $\left(140{ }^{\circ} \mathrm{C}\right.$ selama 40 menit) dan berat ( $190^{\circ} \mathrm{C}$ selama 15 menit). Polifenol kulit biji kakao diekstrak menggunakan aseton $70 \%$. Ekstrak polifenol kering dianalisis rendemen, total fenolik, RSA DPPH yang dinyatakan sebagai $\mathrm{IC}_{50}$ dan penghambatan oksidasi asam linoleat. Hasil penelitian menunjukkan bahwa semakin tinggi suhu penyangraian, rendemen yang diperoleh semakin kecil. Ekstrak polifenol kulit biji kakao dengan penyangraian derajat berat mempunyai rendemen paling kecil $(8,07$ $\% \mathrm{~b} / \mathrm{b}$ ). Ekstrak polifenol kulit biji kakao dengan penyangraian derajat sedang mempunyai total fenolik dan aktivitas antioksidan penangkap radikal DPPH paling tinggi yaitu sebesar 21,23 $\pm 0,39 \mathrm{mg}$ EAG/g ekstrak kering dan nilai $\mathrm{IC}_{50}$ $74,31 \pm 0,72 \mu \mathrm{g} / \mathrm{mL}$. Ekstrak polifenol kulit biji kakao mampu menghambat oksidasi asam linoleat. Penyangraian meningkatkan aktivitas penghambatan oksidasi asam linoleat sebesar $6 \%$ bila dibandingkan dengan ekstrak polifenol kulit biji kakao tanpa penyangraian. Perlu dilakukan penelitian selanjutnya untuk identifikasi senyawa antioksidan kulit biji kakao dari hasil penyangraian.
\end{abstract}

Kata kunci: Aktivitas antioksidan; kulit biji kakao; polifenol; derajat penyangraian

\begin{abstract}
Cocoa bean shell is waste from chocolate industry that containing polyphenol $5.78 \%$ and can be used as natural antioxidant source. The most important step in cocoa processing is roasting. Roasting is needed for developing the chocolate flavor. Chocolate industries do their roasting with low, medium and high degree, depend on product's necessity. The objective of this research is to determine the effect of roasting degree toward cocoa bean shell antioxidant activity. Cocoa bean roasted at low degree $\left(110{ }^{\circ} \mathrm{C}\right.$ for 60 minutes $)$, medium $\left(140{ }^{\circ} \mathrm{C}\right.$ for 40 minutes $)$ and high $(190$ ${ }^{\circ} \mathrm{C}$ for 15 minutes). Cocoa bean shell polyphenol was extracted with acetone $70 \%$. Yield, total phenolic, DPPH free
\end{abstract}


radical scavenging activity as $\mathrm{IC}_{50}$ and inhibition of linoleic acid oxidation was analyzed from crude polyphenol extract. The result shows that the increasing of roasting temperature leads to low yield. Cocoa bean shell polyphenol extract with high roasting degree has the lowest yield $(8.07 \% \mathrm{~b} / \mathrm{b})$. While cocoa bean shell polyphenol extract using medium roasting degree has the highest total phenolic and DPPH free radical scavenging activity of $21.23 \pm 0.39 \mathrm{mg} \mathrm{GAE} / \mathrm{g}$ dry extract and $\mathrm{IC}_{50} 74.31 \pm 0.72 \mu \mathrm{g} / \mathrm{mL}$, respectively. Cocoa bean shell polyphenol extract is able to inhibit the linoleic acid oxidation. Roasting enhance the inhibition of linoleic acid oxidation compared to extract without roasting about 6 $\%$. For the future study, it is needed to identify the cocoa bean shell antioxidant compound during roasting.

Keywords: Antioxidant activity; cocoa bean shell; polyphenol; roasting degree

\section{PENDAHULUAN}

Kulit biji kakao (sekitar $15 \%$ dari berat total biji kakao) merupakan limbah dari industri pengolahan cokelat (Kim dkk., 2004). Perkiraan kulit biji kakao yang dihasilkan industri pengolahan cokelat pada tahun 2012 sebanyak 52.500 ton per tahun dan meningkat menjadi 60.000 ton pada tahun 2014. Kulit biji kakao berpeluang untuk dimanfaatkan sebagai sumber antioksidan karena mengandung senyawa polifenol dengan total fenolik sebesar 5,78 \% (Lecumberri dkk., 2007). Polifenol pada kulit biji kakao antara lain prosianidin, epikatekin, p-hydroksibenzoic acid, antosianin, proantosianidin dan clovamid (Arlorio dkk., 2005; Zou dkk., 2012; Gu dkk., 2006).

Tahapan penting dalam pengolahan biji kakao adalah penyangraian yang bertujuan untuk mengurangi kandungan air, memudahkan pemisahan kulit biji dari kotiledon serta untuk mengembangkan cita rasa. Suhu penyangraian biji kakao berbeda-beda tergantung pada penggunaan produk akhir. Penyangraian derajat ringan pada suhu $110-115{ }^{\circ} \mathrm{C}$ selama 60 menit untuk menghasilkan lemak cokelat dan permen cokelat. Penyangraian derajat sedang pada suhu 140 ${ }^{\circ} \mathrm{C}$ selama 35-40 menit untuk menghasilkan bubuk cokelat, pasta cokelat dan cokelat batang. Penyangraian derajat berat pada suhu $190-200{ }^{\circ} \mathrm{C}$ selama $15-20$ menit untuk menghasilkan pasta cokelat hitam (Minifie, 1982).

Penyangraian menyebabkan perubahan senyawa antioksidan. Penyangraian dengan suhu lebih dari $70{ }^{\circ} \mathrm{C}$ menyebabkan kehilangan katekin tetapi dapat meningkatkan level katekin karena epimerisasi (-)-epikatekin menjadi $(-)$-katekin atau $(+)$-katekin (Payne dkk., 2010; Caligiani dkk., 2014). Suhu penyangraian diatas $100{ }^{\circ} \mathrm{C}$ menyebabkan kehilangan flavanol $10 \%$. Semakin tinggi suhu dan waktu penyangraian menyebabkan kehilangan polifenol yang lebih besar (Cruz dkk., 2013). Penyangraian biji kakao menghasilkan total fenolik yang lebih rendah daripada biji kakao tanpa sangrai tetapi ternyata aktivitas antioksidan biji kakao sangrai lebih tinggi daripada biji kakao tanpa sangrai (Arlorio dkk., 2008). Selama penyangraian, protein dan polifenol yang terikat dengan dinding sel (selulosa dan pektin) akan mengalami reaksi Maillard (Bernaert dkk., 2012). Reaksi Maillard adalah reaksi yang terjadi antara gugus amino dengan gugus karbonil apabila keduanya dipanaskan atau disimpan dalam waktu yang relatif lama. Produk akhir dari reaksi Maillard adalah melanoidin yang berpotensi sebagai antioksidan (Rosida dkk., 2006).

Sebagian besar studi mempelajari senyawa antioksidan pada biji kakao dan sedikit yang mempelajari senyawa antioksidan pada kulit biji kakao. Senyawa antioksidan diketahui terdapat pada kulit biji kakao tetapi belum ditemukan informasi tentang pengaruh derajat penyangraian terhadap senyawa antioksidan pada kulit biji kakao. Penelitian ini bertujuan untuk mengetahui pengaruh derajat penyangraian terhadap aktivitas antioksidan kulit biji kakao.

\section{METODE PENELITIAN}

\section{Bahan dan Alat}

Bahan baku adalah kulit biji kakao dari biji kakao kering tanpa fermentasi varietas Lindak. Biji kakao diperoleh dari Gunung Kidul. Heksana (Merck), aseton (Mallinckrodt), asam linoleat, reagen DPPH, fero klorida dan ammonium thiosianat (Sigma Aldrich). Bahan kimia untuk analisis adalah analytical grade. Peralatan utama yang digunakan alat sangrai (Roaster Coffee RK-28-RCg UD. Reka Yasa), blender (Philips), ayakan 60 mesh (Retsch 5657 Haan W. Jerman), sentrifuse (IEC UV Damon), rotary evaporator (RV06 ML IKA Werke), oven (Drying Oven MOV 112 Sanyo) dan spektrofotometer (Spectronic 200 Thermo Scientific).

\section{Ekstraksi}

Biji kakao kering disangrai dengan penyangraian derajat ringan $\left(110^{\circ} \mathrm{C}, 60\right.$ menit), sedang $\left(140^{\circ} \mathrm{C}, 40\right.$ menit $)$ dan berat $\left(190{ }^{\circ} \mathrm{C}, 15\right.$ menit). Penentuan ini berdasarkan pada derajat penyangraian yang digunakan oleh industri pengolahan cokelat untuk menghasilkan produk akhir (lemak cokelat, bubuk cokelat atau cokelat hitam). Sampel pembanding digunakan biji kakao kering tanpa penyangraian. Biji kakao kering dikupas sehingga diperoleh nib dan kulit biji kakao. 
Kulit biji kakao diblender kemudian disaring dengan ayakan 60 mesh dan dianalisis proksimat.

20 gram bubuk kulit biji kakao dihilangkan lemaknya menggunakan $40 \mathrm{~mL}$ heksana. Sentrifugasi 2,054xg selama 20 menit. Residu yang diperoleh diekstrak menggunakan pelarut aseton $(70 \% \mathrm{v} / \mathrm{v}) 400 \mathrm{~mL}$. Sentrifugasi 2,054xg selama 30 menit. Pelarut diuapkan sehingga diperoleh ekstrak kental dan kemudian dikeringkan.

\section{Analisis Total Fenolik}

Kandungan total fenolik ditentukan dengan Follin Ciocalteau metode Singleton dkk. (1999). Ekstrak (0,1 mL) ditambah reagen Folin-Ciocalteu $(0,5 \mathrm{~mL})$ dan aquades $(6$ $\mathrm{mL})$. Larutan disimpan pada suhu kamar selama 3 menit kemudian ditambahkan $20 \%$ sodium karbonat (w/v, 1,5 mL) dan aquadest sampai volume $10 \mathrm{~mL}$. Inkubasi selama 2 jam suhu kamar. Absorbansi dibaca pada panjang gelombang $760 \mathrm{~nm}$. Penyiapan blanko dilakukan dengan menggunakan aquades dan reagen yang sama. Standar asam galat dengan konsentrasi 0-250 $\mu \mathrm{M}$. Total fenolik dihitung menggunakan kurva kalibrasi asam galat. Hasil dinyatakan sebagai mg EAG/g ekstrak kering.

\section{Aktivitas Penangkapan Radikal DPPH}

Prosedur pengujian menggunakan metode Burda dan Oleszek (2001). 12,5 mg ekstrak dilarutkan dalam $25 \mathrm{~mL}$ metanol. $1 \mathrm{ml}$ larutan ekstrak ditambah $2 \mathrm{~mL}$ larutan $0,1 \mathrm{mM}$ DPPH. Campuran diinkubasi pada suhu kamar, ruang gelap selama 30 menit dan ditera pada panjang gelombang $517 \mathrm{~nm}$. BHT digunakan sebagai kontrol positif. Aktivitas antioksidan sebagai pengikat radikal bebas dinyatakan sebagai $\mathrm{IC}_{50}(\mu \mathrm{g})$ $\mathrm{mL}$ ) yang menunjukkan konsentrasi ekstrak yang dapat memberikan penghambatan terhadap radikal bebas sebesar $50 \%$.

\section{Aktivitas sebagai Penghambat Oksidasi Asam Linoleat}

Prosedur pengujian menggunakan metode Yen dan Chen (1995). Larutan ekstrak dibuat satu seri pengenceran $10-400 \mu \mathrm{g} / \mathrm{mL}$. Larutan ekstrak serta aseton $70 \%$ (blangko) diambil masing-masing sebanyak $0,5 \mathrm{~mL}$ kemudian ditambahkan 2,5 mL emulsi asam linoleat 0,02 $\mathrm{M} \mathrm{pH} \mathrm{7,0}$ dan $2 \mathrm{~mL}$ buffer fosfat $0,2 \mathrm{M} \mathrm{pH} \mathrm{7,0.} \mathrm{Campuran} \mathrm{diinkubasi}$ pada $37^{\circ} \mathrm{C}$ dan dilakukan pengamatan nilai absorbansi setiap 24 jam dengan cara $4,7 \mathrm{~mL}$ etanol $75 \%$ ditambah $0,1 \mathrm{~mL}$ ammonium thiosianat $30 \%, 0,1 \mathrm{~mL}$ larutan sampel, $0,1 \mathrm{~mL}$ fero klorida $0,02 \mathrm{M}$ dalam 3,5\% $\mathrm{HCl}$. Vortex selama 3 menit kemudian dibaca absorbansinya pada $500 \mathrm{~nm}$. Pengamatan absorbansi blangko dilakukan dengan cara mengganti larutan sampel dengan larutan blangko. Absorbansi yang dimaksud dalam persamaan adalah nilai absorbansi sampel pada saat nilai absorbansi blangko maksimal.

\section{Analisis Statistik}

Rancangan percobaan penelitian ini menggunakan rancangan acak lengkap (RAL) pola satu faktor. Sebagai perlakuan adalah derajat penyangraian yaitu tanpa penyangraian, penyangraian derajat ringan $\left(110{ }^{\circ} \mathrm{C}, 60\right.$ menit), derajat sedang $\left(140{ }^{\circ} \mathrm{C}, 40\right.$ menit) dan derajat berat (190 ${ }^{\circ} \mathrm{C}, 15$ menit). Ulangan dilakukan sebanyak 3 kali. Data yang diperoleh dianalisis menggunakan ANOVA dengan tingkat kepercayaan $95 \%$ dan adanya perbedaan diuji dengan DMRT. Data dinyatakan sebagai rata-rata \pm standar deviasi (SD). Analisis regresi linier, koefisien korelasi dan koefisien determinasi dilakukan untuk menghubungkan parameter kandungan total fenolik dengan \% pengikatan radikal dan aktivitas penghambatan oksidasi asam linoleat.

\section{HASIL DAN PEMBAHASAN}

Berdasarkan hasil analisis proksimat, kulit biji kakao memiliki kandungan lemak relatif lebih rendah dibandingkan biji kakao yang mempunyai kandungan lemak lebih dari $50 \%$ berat kering (Lecumberri dkk., 2007). Kandungan lemak kulit biji kakao hanya sebesar 1,79\% berat kering. Kandungan lemak kulit biji kakao ini lebih rendah daripada penelitian Atindana dkk. (2012) dan Lecumberri dkk. (2007) masingmasing sebesar $6,87 \%$ berat kering dan $6,62 \%$ berat kering. Faktor-faktor yang mempengaruhi kandungan lemak kulit biji kakao antara lain adalah perbedaan varietas, asal dan proses pengolahan (Bruna dkk., 2009). Karbohidrat dan serat kasar merupakan komponen utama dari kulit biji kakao dengan kandungan lebih dari $70 \%$ berat kering. Serat kasar pada kulit biji kakao sebesar 18,44 \% berat kering. Penelitian Atindana dkk. (2012) menyebutkan bahwa kandungan karbohidrat dan serat kasar kulit biji kakao lebih dari $60 \%$ berat kering.

\section{Rendemen}

Rendemen ekstrak polifenol kasar kulit biji kakao ditunjukkan pada Tabel 1. Semakin tinggi derajat penyangraian semakin rendah rendemen yang diperoleh. Hal ini disebabkan karena terjadi degradasi senyawa fenolik pada suhu tinggi (Alonso-Salces dkk., 2001). Penurunan rendemen

Tabel 1. Rendemen ekstrak polifenol kulit biji kakao dengan perbedaan derajat penyangraian

\begin{tabular}{ll}
\hline \multicolumn{1}{c}{ Perlakuan } & $\% \mathrm{~b} / \mathrm{b}$ \\
\hline Tanpa penyangraian & 32,61 \\
Penyangraian derajat ringan & 20,47 \\
Penyangraian derajat sedang & 16,94 \\
Penyangraian derajat berat & 8,07 \\
\hline
\end{tabular}


ekstrak polifenol kasar kulit biji kakao yang disangrai juga disebabkan oleh reaksi oksidasi polifenol akibat pemanasan (Haryadi dan Supriyanto, 2012).

\section{Kandungan Total Fenolik}

Kandungan total fenolik dalam ekstrak polifenol kasar kulit biji kakao dengan perbedaan derajat penyangraian dapat dilihat pada Tabel 2 .

Secara statistik derajat penyangraian menunjukkan beda nyata antara masing-masing ekstrak. Hal tersebut berarti bahwa derajat penyangraian mempunyai pengaruh terhadap kandungan fenolik. Total fenolik semakin meningkat dengan peningkatan derajat penyangraian sampai suhu $140{ }^{\circ} \mathrm{C}$ dan mengalami penurunan pada suhu $190{ }^{\circ} \mathrm{C}$. Peningkatan total fenolik disebabkan karena ekstrak polifenol masih berupa ekstrak kasar, sehingga masih tercampur dengan bahan lain misalnya senyawa redukton (misalnya enaminol).

Selama penyangraian, protein dan polifenol akan mengalami reaksi Maillard menghasilkan melanoidin yang berpotensi sebagai penangkal radikal bebas dan mampu membentuk struktur redukton yaitu enaminol (Rosida dkk., 2006). Peningkatan total fenolik juga diakibatkan meningkatnya pelepasan komponen fitokimia dari matriks sel seperti asam-asam fenolik. Proses termal dapat merusak membran sel dan dinding sel serta melepaskan komponen fenolik terlarut dari ikatan ester yang bersifat tidak larut (Dewanto dkk., 2002).

Total fenolik penyangraian derajat berat lebih rendah daripada penyangraian derajat sedang, karena pada suhu tinggi terjadi degradasi senyawa fenolik. Semakin tinggi suhu dan waktu penyangraian menyebabkan kehilangan polifenol yang lebih besar (Cruz dkk., 2013). Selama penyangraian, kandungan fenolik menurun karena oksidasi non enzimatis dari senyawa polifenol. Oksidasi polifenol diikuti dengan polimerisasi dan pembentukan senyawa pigmen. Penurunan fenolik juga disebabkan reaksi senyawa fenolik dengan protein (Arlorio dkk., 2008).

Tabel 2. Total fenolik dalam ekstrak polifenol kasar kulit biji kakao

\begin{tabular}{lc}
\hline \multicolumn{1}{c}{ Perlakuan } & $\begin{array}{c}\text { Total fenolik }(\mathrm{mg} \text { EAG/g } \\
\text { ekstrak kering) }\end{array}$ \\
\hline Tanpa penyangraian & $17,72 \pm 0,28^{\mathrm{a}}$ \\
Penyangraian derajat ringan & $18,40 \pm 0,28^{\mathrm{ab}}$ \\
Penyangraian derajat sedang & $21,23 \pm 0,39^{\mathrm{c}}$ \\
Penyangraian derajat berat & $18,70 \pm 0,19^{\mathrm{b}}$ \\
\hline
\end{tabular}

Keterangan: notasi statistik yang berbeda menunjukkan berbeda nyata

\section{Aktivitas Penangkapan Radikal DPPH}

Aktivitas penangkapan radikal bebas DPPH oleh ekstrak polifenol kulit biji kakao ditunjukkan pada Gambar 1.

Ekstrak polifenol kulit biji kakao dengan penyangraian derajat sedang memperlihatkan aktivitas penangkapan radikal DPPH tertinggi pada konsentrasi 50-75 $\mu \mathrm{g} / \mathrm{mL}(26,62$ $\pm 0,43-54,12 \pm 0,18 \%$ ) dibandingkan ekstrak lain. Ekstrak polifenol kulit biji kakao dengan penyangraian derajat sedang pada konsentrasi $100 \mu \mathrm{g} / \mathrm{mL}$ lebih tinggi daripada ekstrak dari penyangraian derajat ringan tetapi tidak berbeda nyata dengan ekstrak dari penyangraian derajat berat. Ekstrak polifenol kulit biji kakao dengan penyangraian derajat sedang pada konsentrasi $200 \mu \mathrm{g} / \mathrm{mL}$ tidak berbeda nyata dengan ekstrak polifenol yang disangrai. Aktivitas antioksidan fenolik sebagai penangkap radikal bebas dikaitkan dengan kemampuan antioksidan tersebut sebagai donor proton. Jumlah proton hidrogen yang dapat didonorkan dipengaruhi jumlah dan posisi gugus hidroksil aromatik atau hidroksil dari komponen fenolik (Lai dkk., 2001; Su dkk., 2004). Perhitungan nilai $\mathrm{IC}_{50}$ dilakukan pada ekstrak polifenol kulit biji kakao yang telah diketahui aktivitas antioksidannya dan ditunjukkan pada Tabel 3.

Ekstrak polifenol kulit biji kakao dengan penyangraian derajat sedang mempunyai nilai $\mathrm{IC}_{50}$ paling rendah yang berarti bahwa aktivitas antioksidannya paling tinggi dibandingkan ekstrak yang lain. Penyangraian pada kakao

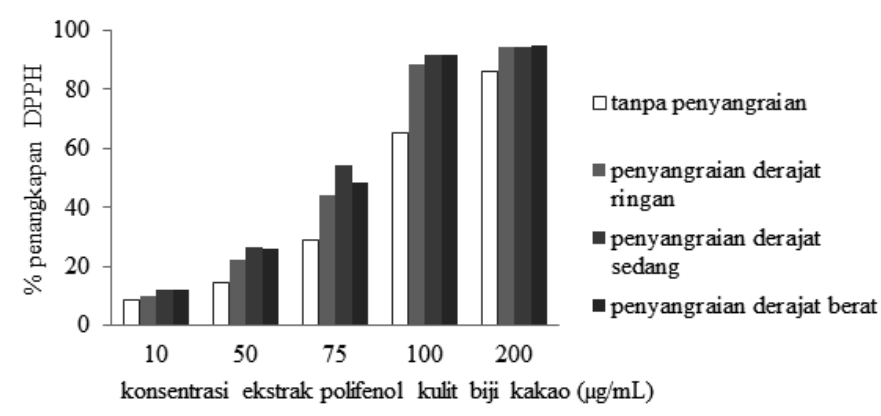

Gambar 1. Aktivitas penangkapan radikal bebas DPPH oleh ekstrak polifenol kulit biji kakao pada berbagai konsentrasi

Tabel 3. Nilai $\mathrm{IC}_{50}$ ekstrak dengan metode DPPH

\begin{tabular}{lc}
\hline \multicolumn{1}{c}{ Ekstrak } & $\begin{array}{c}\text { Aktivitas penangkapan } \\
\text { radikal } \mathrm{DPPH} \mathrm{IC}_{50}(\mu \mathrm{g} / \mathrm{mL})\end{array}$ \\
\hline Tanpa penyangraian & $107,93 \pm 0,43^{\mathrm{e}}$ \\
Penyangraian derajat ringan & $83,01 \pm 0,53^{\mathrm{d}}$ \\
Penyangraian derajat sedang & $74,31 \pm 0,72^{\mathrm{b}}$ \\
Penyangraian derajat berat & $77,35 \pm 0,13^{\mathrm{c}}$ \\
BHT & $68,99 \pm 0,11^{\mathrm{a}}$ \\
\hline
\end{tabular}

Keterangan: notasi statistik yang berbeda menunjukkan berbeda nyata 
menyebabkan terbentuknya senyawa clovamid. Kulit biji kakao yang disangrai pada suhu $100^{\circ} \mathrm{C}$ mengandung clovamid sebanyak 1,817 $\pm 0,059 \mathrm{mg} / \mathrm{kg}$ bubuk kering (Arlorio dkk., 2008). Senyawa clovamid mempunyai kemampuan bertindak sebagai penangkap radikal bebas yang lebih besar dibanding katekin dan epikatekin (Sanbongi dkk., 1998).

Polifenol golongan flavonoid mengandung gugus $\mathrm{OH}$ lebih banyak dibandingkan dengan antioksidan sintetis seperti BHT yang hanya mengandung satu gugus OH (Shahidi, 1997). Ekstrak polifenol kulit biji kakao memiliki aktivitas penangkap radikal DPPH yang lebih rendah daripada standar BHT $\left(\mathrm{IC}_{50} 68,99 \pm 0,11 \mu \mathrm{g} / \mathrm{mL}\right)$. Hal ini disebabkan oleh ekstrak polifenol kasar masih tercampur dengan senyawa lain yang ikut terekstraksi sedangkan senyawa BHT dalam keadaan murni.

\section{Aktivitas Penghambatan Oksidasi Asam Linoleat}

Nilai absorbansi ekstrak polifenol kulit biji kakao pada berbagai derajat penyangraian bertambah besar sejalan dengan lama inkubasi (Gambar 2).

Semakin besar nilai absorbansi, menunjukkan bahwa aktivitas penghambatan oksidasi asam linoleat makin rendah. Sampel blangko menunjukkan nilai absorbansi tertinggi dicapai setelah inkubasi 5 hari. Hasil perhitungan aktivitas penghambatan oksidasi asam linoleat oleh ekstrak polifenol kulit biji kakao ditunjukkan pada Gambar 3.
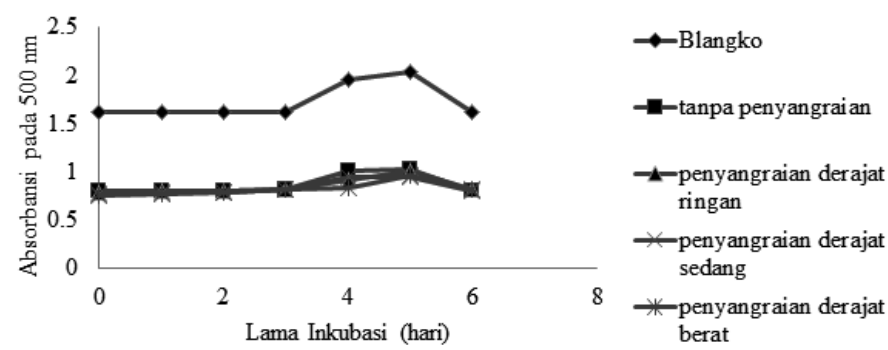

Gambar 2. Nilai absorbansi ekstrak polifenol kulit biji kakao pada berbagai derajat penyangraian

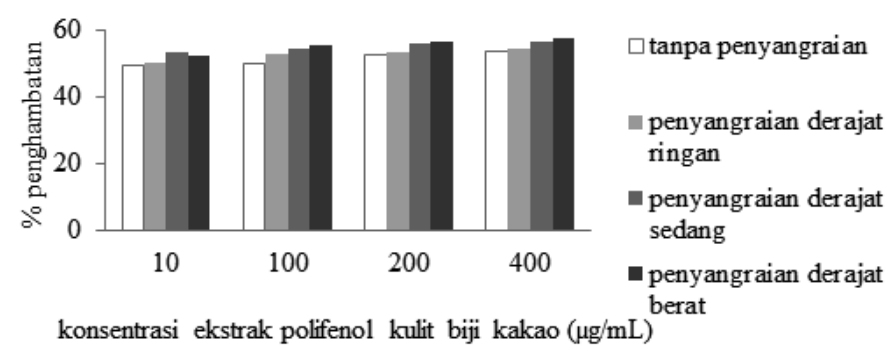

Gambar 3. Aktivitas penghambatan oksidasi asam linoleat oleh ekstrak polifenol kulit biji kakao dengan derajat penyangraian berbeda pada berbagai konsentrasi
Aktivitas penghambatan oksidasi asam linoleat oleh ekstrak polifenol kulit biji kakao yang disangrai lebih besar dibandingkan tanpa penyangraian $(p<0,05)$. Perbedaan tersebut terlihat pada semua konsentrasi. Ekstrak polifenol kulit biji kakao dari penyangraian derajat sedang memiliki penghambatan oksidasi asam linoleat tertinggi pada konsentrasi $10 \mu \mathrm{g} / \mathrm{ml}(53,20 \pm 0,16 \%)$ dibandingkan ekstrak yang lain. Ekstrak polifenol kulit biji kakao dari penyangaraian derajat berat memiliki penghambatan oksidasi asam linoleat tertinggi pada konsentrasi 100-400 $\mu \mathrm{g} / \mathrm{mL}(55,69 \pm 0,14$ $57,46 \pm 0,11 \%$ ) dibandingkan ekstrak yang lain. Kemampuan ekstrak polifenol kulit biji kakao menghambat oksidasi asam lemak linoleat menunjukkan bahwa polifenol kakao dapat berperan sebagai donor proton terhadap radikal peroksil, sehingga radikal tersebut tidak bisa bereaksi dengan asam lemak tidak jenuh untuk membentuk radikal bebas. Dengan demikian dapat memperlambat tahap reaksi propagasi pada proses autooksidasi. Proton hidrogen yang didonorkan dipengaruhi oleh jumlah dan posisi gugus $\mathrm{OH}$ dalam molekul polifenol, sehingga pada konsentrasi polifenol makin besar aktivitas antioksidatifnya juga makin besar (Shahidi, 1997). Semakin banyak gugus hidroksil aromatik, kemampuan penghambatan reaksi berantai pada proses oksidasi lemak semakin efektif dengan cara mendonorkan atom hidrogen atau berperan sebagai akseptor radikal bebas.

Aktivitas penghambatan oksidasi asam linoleat oleh ekstrak polifenol kulit biji kakao yang disangrai justru lebih tinggi dibandingkan dengan yang tidak disangrai, padahal pada ekstrak yang tidak disangrai mestinya polifenol belum banyak mengalami perubahan. Hal tersebut juga terjadi pada biji kakao. Ekstrak polifenol dari biji kakao yang tidak disangrai dapat menghambat oksidasi asam lemak linoleat kurang dari $20 \%$, tetapi setelah disangrai kemampuannya meningkat menjadi $90 \%$ lebih, hampir sama dengan antioksidan sintetis BHT (Supriyanto dkk., 2006). Peningkatan aktivitas antioksidatif selama penyangraian disebabkan karena terbentuknya produk baru yang berpotensi sebagai antioksidan, seperti misalnya produk hasil reaksi antara senyawa karbonil dengan asam amino, reaksi antara produk oksidasi lipid dengan protein dan karbohidrat atau reaksi karamelisasi gula. Penelitian Makris dan Rossiter (2001) juga menunjukkan bahwa produk degradasi morin yaitu $\beta$-resorcylic acid (DHBA) dan phloroglucinol carboxylic acid (PCA) ternyata mempunyai aktivitas antioksidan lebih tinggi daripada morin. Penyangraian menghasilkan produk degradasi fenolik yang mempunyai aktivitas antioksidan lebih tinggi daripada fenolik itu sendiri.

Polifenol merupakan senyawa yang berperan sebagai antioksidan, tetapi pola perubahan polifenol dan perubahan aktivitas antioksidatif dari ekstrak polifenol kulit biji kakao selama penyangraian ternyata berbeda. Pernyataan tersebut 
didukung oleh hasil uji korelasi yang termasuk sedang. Hubungan total fenolik dengan aktivitas penangkapan radikal DPPH berkorelasi dengan nilai $\mathrm{r}$ : 0,496, sedangkan hubungan total fenolik dengan aktivitas penghambatan oksidasi asam linoleat mempunyai nilai $r$ : 0,455. Diduga ada beberapa senyawa fenolik pada ekstrak yang mempunyai aktivitas antioksidan bukan hanya sebagai penangkap radikal bebas tetapi mempunyai mekanisme antioksidan yang lain. Komponen fenolik dapat berperan sebagai antioksidan dengan cara mendonorkan proton hidrogen (antioksidan primer), donor elektron (pereduksi), mengikat ion logam dan mengikat radikal bebas. Korelasi ini menunjukkan bahwa aktivitas antioksidatif tidak selalu disebabkan kandungan fenolik dalam ekstrak polifenol kulit biji kakao. Hal ini disebabkan oleh adanya senyawa lain yang dapat berperan sebagai antioksidan yang terbentuk selama penyangraian, mengingat ekstrak polifenol yang dianalisis masih berupa ekstrak kasar. Aktivitas antioksidatif dapat disebabkan oleh senyawa yang ikut terekstrak seperti metilxanthin, flavonoid dan pigmen (Arlorio dkk., 2005; Othman dkk., 2007).

\section{KESIMPULAN}

Derajat penyangraian mempengaruhi rendemen, total fenolik dan aktivitas antioksidan ekstrak polifenol kulit biji kakao. Ekstrak polifenol kulit biji kakao dengan perbedaan derajat penyangraian diketahui memiliki aktivitas antioksidan yaitu mampu menangkap radikal bebas dan menghambat oksidasi asam linoleat. Ekstrak polifenol kulit biji kakao yang disangrai mempunyai aktivitas antioksidatif lebih tinggi daripada ekstrak polifenol tanpa penyangraian. Ekstrak polifenol kulit biji kakao dari penyangraian derajat sedang memiliki aktivitas penangkapan radikal DPPH tertinggi, yang dinyatakan dengan $\mathrm{IC}_{50}$ yaitu sebesar 74,31 $\pm 0,72 \mu \mathrm{g} /$ mL. Ekstrak polifenol kulit biji kakao dari penyangraian derajat berat memiliki aktivitas penghambatan oksidasi asam linoleat paling tinggi pada konsentrasi $100-400 \mu \mathrm{g} / \mathrm{mL}$ yaitu sebesar 55,69 $\pm 0,14-57,46 \pm 0,11 \%$. Penelitian lebih lanjut diperlukan untuk pemurnian dan identifikasi jenis senyawa polifenol pada kulit biji kakao.

\section{UCAPAN TERIMA KASIH}

Penulis mengucapakan terima kasih kepada BPKIMI Kementerian Perindustrian yang telah membiayai penelitian ini melalui bantuan tunjangan riset Program Rintisan Gelar S3 BPKIMI sesuai Keputusan Kepala BPKIMI Nomor: 50/ BPKIMI/Kep/02/2015 Tanggal 10 Februari 2015.

\section{DAFTAR PUSTAKA}

Alonso-Salces, R.M., Korta, E., Barranco, A., Berrueta, L.A., Gallo, B., Vicente, F. (2001). Pressurized liquid extraction for the determination of polyphenols in apple. Journal Chromatography 933: 37-43.

Arlorio, M., Coisson, J.D., Travaglia, F., Varsaldi, F., Miglio, G., Lombardi, G. dan Martelli, A. (2005). Antioxidant and biological activity of phenolic pigments from Theobroma cacao hulls extracted with supercritical $\mathrm{CO}_{2}$. Food Research International 38: 1009-1014.

Arlorio, M., Locatelli, M., Travaglia, F., Coïsson, J.D., Grosso, E.D., Minassi, A., Appendino, G. dan Martelli, A. (2008). Roasting impact on the contents of clovamide (N-caffeoyl-L-DOPA) and the antioxidant activity of cocoa beans (Theobroma cacao L.). Food Chemistry 106: $967-975$.

Atindana, N.J., Zhong, F., Mothibe, K.J., Bangoura, M.L. dan Lagnika, C. (2012). Quantification of total polyphenolic content and antimicrobial activity of cocoa (Theobroma cacao L.) bean shells. Pakistan Journal of Nutrition 11(7): 574-579.

Bernaert, H., Blondeel, I., Allegaert, L. dan Lohmueller, T. (2012). Industrial treatment of cocoa in chocolate production: health implications. Dalam: Paoletti, R., Poli, A., Conti, A. dan Visioli, F. (eds.) Chocolate and Health, hal 17-31. Springer-Verlag, Italia.

Bruna, C., Eichholz, I., Rohn, S., Kroh, L.W. dan HuyskensKeil, S. (2009). Bioactive compounds and antioxidant activity of cocoa hulls (Theobroma cacao L.) from different origins. Journal of Applied Botany and Food Quality 83: 9-13.

Burda, S. dan Oleszek, W. (2001). Antioxidant and antiradical activities of flavonoids. Journal of Agricultural and Food Chemistry 49: 2774-2779.

Caligiani,A., Palla, L., Acquotti, D., Marseglia,A. dan Palla, G. (2014). Application of ${ }^{1} \mathrm{H}$ NMR for the characterisation of cocoa beans of different geographical origins and fermentation levels. Food Chemistry 157: 94-99.

Cruz, J.F.M., Leite, P.B., Soares, S.E. dan Bispo, E.S. (2013). Assessment of the fermentative process from different cocoa cultivars produced in Southern Bahia, Brazil. African Journal of Biotechnology 12(33): 5218-5225.

Dewanto, V., Wu, X.dan Liu, R.H. (2002). Processed sweet corn has higher antioxidant activity. Journal of Agricultural and Food Chemistry 50 (17): 4959-4964. 
Gu, L., House, S.E., Wu, X., Ou, B. dan Prior, R.L. (2006). Procyanidin and catechin contents and antioxidant capacity of cocoa and chocolate products. Journal of Agricultural and Food Chemistry 54: 4057-4061.

Haryadi dan Supriyanto. (2012). Teknologi Cokelat. Gadjah Mada University Press, Yogyakarta.

Kim, K.H., Lee, K.W., Kim, D.Y., Park, H.H., Kwon, I.B. dan Lee, H.J. (2004). Extraction and fractionation of glucosyltransferase inhibitors from cacao bean husk. Process Biochemistry 39: 2043-2046.

Lai, L.S., Chou, S.T., dan Chao, W.W. (2001). Studies on the antioxidative activities of Hsian-tsao (Mesona procumbens Heinsl) leaf gum. Journal of Agricultural and Food Chemistry 49(2) : 963-968.

Lecumberri, E., Mateosa, R., Pulido, M.I., Ruperez, P., Goya, L. dan Bravo, L. (2007). Dietary fibre composition, antioxidant capacity and physico-chemical properties of a fibre-rich product from cocoa (Theobroma cacao L.). Food Chemistry 104: 948-954.

Makris, D.P. dan Rossiter, J.T. (2001). Comparison of quercetin and a non-orthohydroxy flavonol as antioxidants by competing in vitro oxidation reactions. Journal of Agricultural and Food Chemistry 49: 33703377.

Minifie, B.W. (1982). Chocolate, Cocoa and Confectionery. AVI Publ. Co. Inc., Wesport, Conecticut.

Othman, A., Ismail, A., Ghani, N.A., dan Adenan, I. (2007). Antioxidant capacity and phenolic content of cocoa beans. Food Chemistry 100: 1523-1530.

Payne, M.J., Hurst, W.J., Miller, K.B., Rank, C. dan Stuart, D.A. (2010). Impact of fermentation, drying, roasting, and dutch processing on epicatechin and catechin content of cacao beans and cocoa ingredients. Journal of Agricultural and Food Chemistry 58: 10518-10527.
Rosida, D.F., Fardiaz, D., Apriyantono, A dan Andarwulan, N. (2006). Isolasi dan karakterisasi melanoidin kecap manis dan peranannya sebagai antioksidan. Jurnal Teknologi dan Industri Pangan XVII (3): 204-213.

Sanbongi, C., Osakabe, N., Natsume, M., Takizawa, T., Gomi, S., dan Osawa, T. (1998). Antioxidative polyphenols isolated from Theobroma cacao. Journal of Agricultural and Food Chemistry 46: 454-457.

Shahidi, F. (1997). Natural antioxidants chemistry, health effects and applications. AOCS Press. Champaign, Illinois.

Singleton, V.L., Orthofer, R. dan Lamuela-Raventós, R.M. (1999). Analysis of total phenols and other oxidation substrates and antioxidants by means of Folin-Ciocalteu reagent. Meth. Enzymology 299: 152-178.

Su, Y.L., Xu, J.Z., Ng, C.H., Leung, L.K.K., Huang, Y.dan Chen, Z.C. (2004). Antioxidant activity of tea theaflavins and methylated catechin in canola oil. Journal of the American Oil Chemists'Society 31(3): 269-274.

Supriyanto, Haryadi, Rahardjo, B. dan Marseno, D.W. (2006). Aktivitas antioksidan ekstrak polifenol kasar dari kakao hasil penyangraian menggunakan enerji gelombang mikro. Jurnal Teknologi dan Industri Pangan XVII(3): 176-182.

Yen, G.C. dan Chen, H.Y. (1995). Antioxidant activity of various tea extracts in relation to their antimutagenicity. Journal of Agricultural and Food Chemistry 43: 27-32.

Zou, T., Susan, P., Cheng, Q., Li, Z., Rowe, C.A. dan Gu, L. (2012). Preparation, characterization, and induction of cell apoptosis of cocoa procyanidins-gelatin-chitosan nanoparticles. European Journal of Pharmaceutics and Biopharmaceutics 82: 36-42. 